\title{
Students with Special Needs in Digital Classrooms during the COVID- 19 Pandemic in Turkey
}

\author{
Gulcihan Yazcayir $^{1 *}$, Hasan Gurgur ${ }^{2}$
}

${ }^{1}$ Usak University, TURKEY

${ }^{2}$ Eskisehir Anadolu University, TURKEY

${ }^{\star}$ Corresponding Author: gulcihanyazcayir@gmail.com

Citation: Yazcayir, G., \& Gurgur, H. (2021). Students with Special Needs in Digital Classrooms during the COVID-19 Pandemic in Turkey. Pedagogical Research, 6(1), em0088. https://doi.org/10.29333/pr/9356

ARTICLE INFO
Received: 6 Sep. 2020
Accepted: 21 Nov. 2020

\begin{abstract}
In this study, the aim is to examine how special education provided for students within inclusive education has continued at home during the pandemic. This study has employed phenomenology as the research method because this design enables researchers to make in-depth analysis and description. Purposeful sampling method was utilized to determine the participants of the study. Research participants consists of 15 voluntary parents of students with special needs who continued their education through inclusive education conducted in general education classes. Participating parents' children were between 9-to-14 years of age and were studying at a grade between the $3^{\text {rd }}$ and $8^{\text {th }}$ grades. Research data have been collected through semi-structured interviews and analyzed by inductive method. research results have shown that all students, including those with special needs, have continued their schooling via distance education provided by Turkish Ministry of National Education through EBA TV and the official website of the Ministry. In addition, participants have reported that some teachers conducted online lessons and shared worksheets with all students via the WhatsApp group. However, several issues of concern have also been noted as follows: students with special needs could not follow the lessons on TV regularly, many of them did not attend online lessons, and their teachers did not give feedback about their activities. Moreover, none of the students with special needs received support education services, and there was no communication and cooperation among teachers, families, and students. Furthermore, the findings have indicated that children were unwilling and unable to adapt to distance education.
\end{abstract}

Keywords: inclusive education, distance education, students with special needs, COVID-19, pandemic

\section{INTRODUCTION}

According to the figures in the latest report of the World Health Organization (WHO), there are nearly twenty-seven million cases worldwide and the number is increasing day by day due to the pandemic caused by the Corona virus. At the same time, nearly 900 thousand people had been killed by the virus as of September 6 (WHO, 2020). Some emergency measures such as school closures, travel restrictions, social distancing and quarantine have been taken in many countries as this global pandemic has been growing day by day (Orgilés et al., 2020; Van Lancker \& Parolin, 2020). Going to school during the pandemics is considered to play a major role in the spread of the infection due to the interactions among school-age children (Monto et al.,1969; Reichert et al., 2001). For this reason, school closure strategy is thought as an effective measure in preventing the infection of others and controlling the spread of the disease in the community, especially in the early stages of the pandemic (Cauchemez et al., 2009, Halder et al., 2010; Van Lancker \& Parolin, 2020). On the other hand, it is also known that children have been in physical and social isolation in their homes due to school closures during the pandemic. Therefore, various regulations have been made to minimize the negative effects of the pandemic on education.

In order to ensure the continuity of education for school-age children throughout the world during the pandemic period, distance education process has been commenced through various technological tools and Internet-based education systems (Zhou et al., 2020). In this context, online face-to-face lessons allowing attendance of many people and offline lessons on websites have been made available by taking advantage of modern education technology (Onyema et al., 2020; World Bank, 2020a). However, infrastructure and technological savvy of teachers to use distance education tools functionally are important in the success of distance education. For example, China, with a strong technological infrastructure, is successful in providing distance education, but it is reported that some countries such as Vietnam and Mongolia struggle with difficulties in carrying out distance education process with low Internet networks, smartphones, or televisions (World Bank, 2020b). On the other hand, even before COVID-19, it was known that all students in the world did not have the same opportunities in terms of access to devices such as computers, tablets, and the Internet (Fry-Bowers, 2020). Most school districts serving, especially, children of low-income families 
or children in rural areas are deprived of necessary resources for an effective transition to distance education (Fishbane \& Tomer, 2020; Van Lancker \& Parolin, 2020). It is emphasized that a rapid transition without taking into account the factors influential over the success of distance education may increase present inequalities (Onyema et al., 2020; World Bank, 2020b). In this context, the quality of education all over the world has been negatively affected from school closures during the pandemic. Coupled with the fact that every student doesn't have equal access to distance education, the consequences of the pandemic creates problems in equality and equity in education (Andrew et al., 2020; Doyle, 2020; Mustafa, 2020; Onyema et al., 2020; Sahu, 2020; Zhou et al., 2020). In addition, the pandemic significantly reduced support services provided for students with special needs by specialists such as special education teachers, speech and language therapists, and psychologists (Petretto et al., 2020). However, the main purpose of educating students with special needs is to ensure their integration with the society by providing equal and effective educational services both in special education schools and through inclusive education. The most effective way to achieve this integration is to make sure that students with special needs continue to receive support and general education services together with their peers according to an Individualized Education Program (IEP) in the least restrictive educational environment - general education classes (Friend \& Bursuck, 2012; Hornby, 2015; Mitchell, 2008; Turnbull et al., 2013). However, in the literature, it is emphasized that students with special needs or disadvantages are under a serious risk because distance education is the only medium that can meet their educational needs (Schaeffer, 2020; Toquero, 2020).

In addition to accessibility of distance education, collaboration between families and teachers has also become more important so that students can benefit from the process during this period (Cai \& Wang, 2020; Kritzer \& Smith, 2020; Mustafa, 2020; Zheng, 2020). Families are important guides in the development of their children. However, in daily life, families can be very busy with work life and housework. Consequently, they may neglect their children's education (Cai \& Wang, 2020). Furthermore, they can feel overwhelmed due to the reasons such as prolongation of the quarantine, losing their jobs and income, prolonged shutdowns and not being able to meet their children's educational and daily life needs, etc. (Akoğlu \& Karaaslan, 2020; Fry-Bowers, 2020). It is known that families found more time to take care of their children and to fulfill their responsibilities for their children's learning at the beginning of the pandemic (Cai \& Wang, 2020). In this sense; it is accepted that negative changes in education, social, economic, and daily life increase the anxiety levels of families and students (Cao et al., 2020; Sahu, 2020; Zhou et al., 2020). In addition, it is reported that the duration and quality of family support in distance learning varies according to the socioeconomic structure and education level of the family (World Bank, 2020b).

As in many countries in the world, the Ministry of National Education (MONE) decided to close schools for two weeks right after the first case was detected in Turkey on March 10, 2020. One week later, considering the limitations of the Internet and computer access, the MoNE started distance education process via EBA TV, which is a television channel. In the following weeks, it was announced that the schools would stay closed until the end of the academic year, and distance education process would be delivered on the Internet portal of MoNE. Additionally, in line with the programs determined by each school administration, online lessons were provided to students by their teachers. In this process, every grade (1-12 ${ }^{\text {th }}$ grades) received education with adapted educational content prepared in accordance with their levels via EBA TV and the Internet portal. Online lessons were carried out via Zoom and similar applications. In addition to general education lessons, disadvantaged students were provided with special education lessons and school age non-Turkish children under the protection of Turkish government were also supported for Turkish lessons through EBA TV and the portal (MoNE, 2020a; Özer, 2020).

Many studies report that the pandemic has negative effects on children and their education (Cao et al., 2020; Mustafa, 2020; Onyema et al., 2020; Sahu, 2020; Zhou et al., 2020). In the meantime, some other studies put forth suggestions to minimize these effects (Berger et al., 2020; Cai \& Wang, 2020; Van Lancker \& Parolin, 2020). However, literature review yielded that studies focusing on students in the disadvantaged group were quite limited. Internationally, some studies investigated how the psychological effects of the pandemic could be lessened on students with special needs and their families (Asbury et al., 2020). Besides, some others searched what kind of support families of children with special needs needed for their children's education and their mental health (Toseeb et al., 2020). In the national literature, there are studies that discuss the possible psychosocial effects of the pandemic period on education (Mustafa, 2020) and children (Akoğlu \& Karaaslan, 2020). However, neither in the international nor in the national literature, there is in depth research on how students with special needs who continue their education through inclusive education, or who study in separate schools and classes, continue their distance education at home during the pandemic. Based on the findings of this study, it is thought that some suggestions could be made to the practitioners regarding the distance education processes of students with special needs. Considering the concerns of many families that schools will not open in the new academic year (Grayer et al., 2020), it is assumed that constructing more qualified distance education structures for students with special needs in the upcoming period would be significant. In this study, the aim is to examine how special education within inclusive settings has continued for students with special needs during the pandemic. The problem sentence of the research is "How do students with special needs continue their education through digital classrooms at home during the COVID-19 pandemic?" Answers were sought to the following sub-questions related to this problem statement:

1) What kinds of practices are carried out based on emergency distance education during the COVID-19 pandemic process for students with special needs who continue their education through digital classrooms?

2) What are the problems students with special needs who continue their education through digital classrooms encountered during the COVID-19 quarantine?

3) What are the expectations of families about the education of their children with special needs who continue their education through digital classrooms during the COVID-19 pandemic? 


\section{METHODOLOGY}

\section{Research Design}

In this study, the researcher employed phenomenological design in order to produce an in-depth examination and description outlining how distance education processes were carried out for students with special needs during schools were closed because of the COVID-19 pandemic (Creswell, 2007; Given, 2008; Mertens, 2010). Phenomenological research aims to produce an in-depth description of the lives of individuals who experience a phenomenon (Moustakas, 1994). Accordingly, this study focuses on the families of students with special needs as they are important stakeholders of education. At the same time, they share their children's experiences with distance education during the COVID-19 pandemic and they also provide one-on-one support as the primary caregivers for their children during these difficult times. Thus, an answer has been sought for the question "How do students with special needs continue their education through digital classrooms at home during the COVID-19 pandemic?"

\section{Data Collection Technique}

Research data were collected through semi-structured interviews, one of the qualitative data collection techniques (Creswell, 2007; Given, 2008). As a result of social isolation requirement during the pandemic, it has become a serious risk for people to be in the same place with others. For this reason, online interviews were held using the ZOOM meeting program and phone calls, which made it easy to utilize the space and time flexibility provided by the Internet (Crabtree \& Miller, 1999; Markham, 2004). The interviews were carried out between June 5 and 15 2020, and all were audio-recorded. The total duration of all the interviews is 2 hours and 48 minutes.

\section{Participants}

Considered useful in explaining the case to be studied (Mertens, 2010; Miles \& Huberman, 1994), purposeful sampling method was utilized to determine the participants of the study. Accordingly, research participants consists of voluntary parents of students with special needs who continued their education through inclusive education conducted in general education classes. Participating parents' children were between 9-to-14 years of age and were studying at a grade between the $3^{\text {rd }}$ and $8^{\text {th }}$. While identifying the participants, the parents of all students who continued their education within inclusion were called to explain the purpose of the study. They were asked whether they would volunteer to participate, and 15 parents of children with special needs who continued their education in inclusive education agreed to partake in the current study. Thus, this study has been conducted with the participation of 15 parents of children with special needs who continued their education through inclusive education in general education classes.

In accordance with research ethics, participants' names aren't given here. Instead, code names such as Parent-1, Parent-2... are used for each participant. Demographic information about parents is shown in Table 1.

Table 1. Demographic characteristics of the participants

\begin{tabular}{|c|c|c|c|c|c|}
\hline Participants & $\begin{array}{l}\text { Students' } \\
\text { class grades }\end{array}$ & Diagnosis of the children & $\begin{array}{l}\text { Number of children/ number of } \\
\text { children with special needs }\end{array}$ & $\begin{array}{l}\text { Level of household } \\
\text { income }\end{array}$ & $\begin{array}{c}\text { Parents' education } \\
\text { level }\end{array}$ \\
\hline Parent-1 & 5 & Specific learning impairment & $2 / 1$ & Middle & Primary school \\
\hline Parent-2 & 6 & Specific learning impairment & $3 / 1$ & High & Primary school \\
\hline Parent-3 & 7 & Specific learning impairment & 2 (twin)/1 & Middle & Primary school \\
\hline Parent-4 & 8 & Intellectual disability & $2 / 2$ & High & Primary school \\
\hline Parent-5 & 5 & Specific learning impairment & $2 / 1$ & Middle & Primary school \\
\hline Parent- 6 & 8 & Intellectual disability & $2 / 1$ & High & Secondary school \\
\hline Parent-7 & 8 & ADHD & $2 / 1$ & Middle & Primary school \\
\hline Parent-8 & 8 & ADHD & $3 / 1$ & Middle & Primary school \\
\hline Parent-9 & 6 & Specific learning impairment & 2 (twin)/2 & Middle & Primary school \\
\hline Parent-10 & 4 & Multiple disabilities & 1 & Middle & Primary school \\
\hline Parent-11 & 4 & Pervasive developmental disorder & $3 / 1$ & Middle & Primary school \\
\hline Parent-12 & 3 & Specific learning impairment & $2 / 1$ & Middle & Primary school \\
\hline Parent-13 & 4 & Specific learning impairment & 1 & Middle & Primary school \\
\hline Parent-14 & 3 & Speech and language disorder & $2 / 1$ & High & Bachelor's degree \\
\hline Parent-15 & 4 & Speech and language disorder & 1 & High & Bachelor's degree \\
\hline
\end{tabular}

$\mathrm{ADHD}^{*}=$ Attention Deficit Hyperactivity Disorder

As seen in Table 1, the children of participating parents are between the $3^{\text {rd }}$ and $8^{\text {th }}$ grades. Most parents have children with specific learning impairment. Besides, two parents have two children with special needs while most of the participating parents have just only one child with special needs. The income levels of families are stated as reported by parents. According to this, while middle income families only have one fixed income of the mother or father; families with high income have a fixed income of both mother and father. As for the education level of parents, most are primary school graduates. Finally, it is known that working mothers were also on leave during the quarantine.

\section{Data Analysis}

The analysis of research data was carried out in accordance with the inductive approach. The data collected through video conferencing and phone calls were recorded digitally as short notes and voice recordings. Then, the audio recordings in digital environment were transcribed into texts. Comparing the emerging code clusters together, researchers worked independently on these documents and coded them. The main and sub-themes were organized and reorganized until consensus was reached 
(Bogdan \& Biklen, 2007; Creswell, 2007; Given, 2008; Miles \& Huberman, 1994). The validity and reliability of the themes are discussed in the next section.

\section{Validity, Reliability and Ethics}

In this study, various measures were taken for validity and reliability. In this sense, first of all, the agreement percentage formula of Miles \& Huberman (1994) (Reliability = consensus / (agreement + disagreement) x 100) was employed for reliability analysis. According to Miles \& Huberman (1994), the reliability of a research in qualitative studies is achieved in cases where the fitness between expert's and researcher's evaluations is $90 \%$ and above. At the end of the reliability analysis performed for this study, the percentage of agreement was determined as $99 \%$ for the codes. In addition, detailed descriptions through direct quotations from participants' views were also included in the study (Creswell, 2007; Miles \& Huberman, 1994). Necessary consents and approvals were secured from the participants in accordance with research ethics. They were also informed that they had the right to withdraw from the study whenever they wanted.

\section{FINDINGS}

As a result of analyzing data obtained during the research process, three themes emerged. Themes and sub-themes are shown in Figure 1.

\begin{tabular}{|ll|}
\hline Distance Learning Practices & $\begin{array}{l}\text { - General Education Practices } \\
\text { - Support Education Services }\end{array}$ \\
\hline $\begin{array}{l}\text { Problems During the Quarantine } \\
\begin{array}{l}\text { Expectations of Families Regarding } \\
\text { the Education of Their Children }\end{array}\end{array}$ & $\begin{array}{l}\text { Teaching } \\
\text { P Psychosocial Problems }\end{array}$ \\
\hline
\end{tabular}

Figure 1. Theme and Sub-Themes in the Study

\section{Distance Learning Practices}

The theme of "Distance Learning Practices" emerged as a result of the analysis of the data obtained from the interviews with the participating parents. Under this main theme, two sub-themes emerged - "General Education Practices" and "Support Education Services." Table 2 shows the findings on sub-themes.

Table 2. Table of Findings Regarding Sub-Themes under the main Theme of Distance Learning Practices

\begin{tabular}{cc}
\hline Main theme “Distance learning practices” and sub-themes & Frequency (f) \\
\hline General Education Practices & \\
\hline Watching lessons on TV & 9 \\
\hline Attending online classes in addition to the lessons on TV & 2 \\
\hline Sharing Worksheets on WhatsApp class group & 60 \\
\hline Doing nothing & 6 \\
\hline Support Education Services & 13 \\
\hline No distance education from school & 40 \\
\hline Getting remote support education from a private education institution & 15 \\
\hline
\end{tabular}

Detailed explanations about the findings in Table 2 are given below.

\section{General education practices}

This sub-theme presents findings about what kind of arrangements there are in general education practices for students with special needs in distance education and how the process works. Accordingly, as can be understood from the statement of Parent10 - "We watched the EBA on television" - most participants watched lessons on TV during the distance education process. In addition to watching lessons on TV 2 participants stated that they followed online lessons: "Our classroom teacher gave online lessons. We tried to join them as best we could. " (Parent-10). Apart from television and online lessons, six participants stated that worksheets were sent by teachers on WhatsApp group of the class. However, some participants said that they failed to help their children with their studies as Parent-1 who said "The teachers shared homework on WhatsApp group. I am a primary school graduate; I don't understand anything ... I don't know if he was able to do it." Also, it was figured that teachers just prepared, photographed, and sent these worksheets to students, but they could not or did not provide any feedback on how they were doing. One participant (Parent-9) stated, "The teachers did not confirm if students' answers on the tests were true or false." During the pandemic, in addition to the nine students who followed lessons provided via television or the Internet, six students did not do anything about their education. Parent-8 stated, "He did nothing about the lesson. He didn't want to study anyway. I was forcing him to go to school. He neither opened a book, nor watched the lesson on the TV or the Internet." 


\section{Support education services}

Another sub-theme that emerged in this study under the main theme "Distance Learning Practices" is "Support Education Services". Accordingly, all the participating parents stated that no teacher from any school provided support education services to their children and they did not even call them privately. For example, Parent-11 stated, "Support education was not provided. There has never been such an offer... The teachers never called. Nobody said anything about what to do". Some participants expressed that this may be due to the problems experienced in the past with the teachers of their children as Parent-11 said "Maybe it is because we had an argument in the beginning." and Parent-8 said, "I did not get any support from any of the teachers. The teachers were all fed up. There were always complaints at the school..." Only one participant (Parent-5) stated that although she called the class teacher on the phone, nothing was done, "We could not meet with the teachers from the school either. Only $a$ few times the English teacher called. They cannot support us". In addition to the support services in the school, only one student benefitted from online support education services offered to students with special needs by private special education institutions during the quarantine. Parent-1 stated, "I was called from special education. They taught one-to-one online lessons.". The other 14 participants stated that they did not receive support education services from private special education institutions. Parent-10 stated, "We didn't get any support from there either" while Parent 2 stated, “... didn't call either. Because of the corona, everything is over."

\section{Problems during the Quarantine}

As a result of data analysis, another main theme identified was "Problems During the Quarantine". Under this main theme, two sub-themes emerged such as "Problems Related to Distance Education" and "Psychosocial Problems". Table 3 shows the findings regarding these sub-themes.

Table 3. Table of Findings Regarding Sub-themes Related to the Problems During the Quarantine

\begin{tabular}{cc}
\hline The main theme “Problems During the Quarantine" and sub-themes & Frequency (f) \\
\hline Problems Related to Distance education & Percentage (\%) \\
\hline Lack of teacher-student-parent coordination & 4 \\
\hline No computer and internet access & 3 \\
\hline Inability to adapt to distance education & 8 \\
\hline An inefficient training process & 15 \\
\hline Psychosocial Problems & 53 \\
\hline Being away from friends and being unable to socialize & 3 \\
\hline Sleep pattern change & 20 \\
\hline Getting fat & 20 \\
\hline Sibling conflict & 13 \\
\hline Being Bored, overwhelmed & 7 \\
\hline & 7 \\
\hline
\end{tabular}

Detailed explanations on the findings in Table 3 are given below.

\section{Problems regarding distance education}

The analysis of the interviews conducted in this study indicated some problems such as the inability to establish coordination among teachers, students, and parents; lack of computer and Internet Access; and an inefficient distance education process. Four participating parents reported having problems regarding the fact that distance education process was not carried out in cooperation with teachers, Parent-15 stated, "There was no coordination among students, parents, and teachers." On the other hand, three parents stated that their children had problems in distance education due to lack of access to the Internet or computers. For example, Parent-7 reported, "There was no Internet at home. His father has internet access on his mobile phone, but he works at a factory and he couldn't leave his phone at home." In addition, eight participants stated that their children were unwilling and could not adapt to distance education. Parent-9 reported, "They were lazy because of being home, not going to school." In fact, a parent (Parent-14) said that the children acted carelessly and never minded the lessons due to the length of the quarantine period. She said, "At the beginning they did a lot of activities. But as time went on, he became unworried and relaxed a little more." Another parent (Parent 6) reported that her child took quarantine as a vacation. "My school is over. I'm on vacation. My friends do not go to school either. We are on vacation. He always saw the situation that way." As a result, all parents clearly emphasized that distance education process was not efficient, as it was stated by Parent-15, "It was not efficient at all". According to Parent-6, especially for students with special needs, this process turned out to be inefficient.

"They stayed away from education. I did not see any benefit from this distance education. Maybe it is useful for normal children. But for such children it was not useful at all. Children forget it quickly; you cannot advance it. How useful can I be in this period? " (Parent-6)

\section{Psychosocial problems}

From the statements of all participating parents, it was understood that the most important problem in this process was that their children and themselves were very bored and overwhelmed by being in quarantine. Parent-2 reported that her child was severely bored during this process, "The child was terribly bored. I could not restrain him/her. Sometimes she insisted on going out for a stroll but as my house is on the street, she could not go out. "Another parent (Parent-9) stated that the quarantine felt like being locked at home. She said "We were imprisoned at home." In addition to problems such as the boredom and depression of children and families during the quarantine, three parents stated that their children experienced problems due to staying away from their school friends and not being able to socialize. For example, Parent-14 reported, "They could not release their energy. 
They were bored because of the lack of social environment. They missed their friends. They missed the school environment very much. They always asked when the school would open, I wish we were at school. " and Parent-10 said, "The point I feel sorry for my child is that he chose his own friends, became friends and started walking with them, then the Corona broke out." Conversely, another parent (Parent-4) said that her child was not bored but they went to their homes in the countryside and they spent time by surfing on the Internet thanks to smart phones and tablets. "We came to the village. The children could go everywhere from vineyards to gardens in the village. It is not a problem going to your friends' house in the village, and when they have phones and tablets, they cause no problems." On top of feeling being bored at home, two parents stated that entire family's daily sleep patterns changed during the quarantine. Parent-3 stated, "Our sleeping routine is disrupted for both adults and minors." Likewise, Parent-5 said, "Neither the time we sleep nor the time we are awake is certain...". Besides, according to Parent-5, another problem that emerged during this time was the disagreement between siblings. She reported, "They constantly had fights. It's okay if they don't fight. It was very difficult." Another parent, Parent-6, said that her child gained weight during the quarantine process, "My child gained a lot of weight. She was already overweight and gained even more weight because of inactivity".

\section{Families' Expectations regarding their Children's Education}

The last theme that emerged in this research is "Families' Expectations Regarding Their Children's Education" during the quarantine. Table 4 shows the findings about this theme.

Table 4. Table of Findings Concerning the Theme of Families' Expectations Regarding Their Children's Education

\begin{tabular}{ccc}
\hline Families' Expectations Regarding Their Children's Education & \multicolumn{2}{c}{ Frequency (f) } \\
\hline Teachers' support and interest regarding the children's education & 13 & Percentage (\%) \\
\hline No expectation & 87 \\
\hline Support education from private education institution & 13 \\
\hline Technological device from charity to their children & 4 \\
\hline
\end{tabular}

As seen in Table 4, except for two of the participating parents, 13 parents stated that they expected teachers' interest and support in their children's education. Some sample statements from participants are as follows: "It would be better if teachers were interested" (Parent-1) and "I expected support from teachers." (Parent-4). Likewise, especially two parents stated that they expected at least a phone call from teachers, Parent-3 stated, "It would be better if the teacher called and asked, "Why are you not doing your lessons?". Another parent (Parent-6) said, "Online lessons were delivered to normal children. The children like ours demand more attention. They could send text messages on WhatsApp. There is not much attention paid to the children such as ours even during normal times." and Parent-12 stated, "I wish the children had online lessons at least once a week. Then, they wouldn't be alienated from the school this way." Besides, one parent expressed her expectation from teachers regarding the establishment of an effective school-family cooperation not only in this period but also when things are normal by saying:

"I wish my child was taken care of. It would be better if he had some fun and a little lesson. Mothers know their children best. I wish their teachers learn something from mothers. They should ask us what and how our children are doing? When I say something to teachers, they get angry at me and say, "don't teach me my job." (Parent 11)

As for the expectations from teachers, one parent reported being in constant touch with the teacher and not having any expectation from him/her. Parent-14 said "We were in constant contact with our teacher. That's why I didn't have high expectations." Another parent (Parent-8) said that he did not expect anything from anyone due to his child's reluctance, "My child doesn't want to study anyway. If he wanted to, I would have done my best. I don't expect anything from anyone because he doesn't want to study." In addition to the expectations from teachers, four parents stated that they expected the private education institutions to take care of their children during this period. Parent- 6 said:

"I wish that the institution could make an online connection with us at least once a week. Even if there is no lesson, they could at least ask about the situation. They once called and asked how my child was doing activities at home. In addition, they asked me to send them a video of my child doing activities at home just to show off." (Parent-6)

Another parent (Parent-7) said:

"I could not provide opportunities for my child because of my financial situation. I would like something for my child, be it a tablet or a computer."

\section{DISCUSSION}

In this study, the aim is to investigate parents' opinions about how special education is delivered to students with special needs within inclusive education during the COVID-19 pandemic.

Based on the findings, it was revealed that the children with special needs partially watched EBA TV lessons provided by the MoNE during the pandemic. On the other hand, it was determined that online lessons were organized by some teachers during the COVID-19 pandemic process. At the same time, it was understood that teachers shared worksheets on WhatsApp groups for the whole general education classes. But parents could not follow these and left their children alone. It was also found that teachers did not give any feedback to students regarding these worksheets. However, in order for distance education to be successful, it is frequently emphasized in the literature that teachers should communicate with families on the phone after each study to check whether students have done their homework or to give feedback about the work done (Cai \& Wang, 2020; Mustafa, 2020). Also, in 
the literature, it is emphasized that distance education contents and resources should be diversified considering students' characteristics (World Bank, 2020a; Mustafa, 2020; Petretto et al., 2020; Zhou et al., 2020).

Besides the adaptations, the findings of the research revealed that support education services, which are integral for the success of students with special needs, were not offered by school teachers at all during the pandemic. Similarly, it was stated that very few students with special needs received support or most of them were not supported at all during the COVID-19 pandemic process (Kritzer \& Smith, 2020; Weale, 2020). Moreover, the latest statistical data reports that there were 2505 special education and rehabilitation centers that offer educational support services outside schools in Turkey (MONE, 2019) during 2018 and 2019 academic year. Special education service is provided to support students with special needs out of school times through a private education institution by the parents' choice (MoNE, 2012). In this study, it was found out that only one student was provided with distance special education support by a private education institution, and others did not receive any support from anywhere. Similarly, in the world, it is stated that many students with special needs cannot benefit from special education and related support services during the COVID-19 pandemic process (Grayer et al., 2020; Kritzer \& Smith, 2020; Weale, 2020). Considering that the students in question continue their distance education at home without cooperation between families and teachers, teacher guidance and follow-up, and support education services, it can be said that the education of these students has been ignored during this process.

As a result of the analyses, several problems were determined such as the lack of access to computers and the Internet, the inability to establish communication between and among teachers, students, and parents, and lack of cooperation regarding the distance education of students with special needs within the quarantine period during the pandemic. Similarly, it was stated that students with special needs and their families were not contacted by teachers and other relevant staff. This had a negative impact on the physical, emotional and mental health of many of the families and their children. The families had to try carrying out their children's education at home without the support of any specialist or institution. It was determined that families felt forgotten together with their children during this process (Kritzer \& Smith, 2020; Weale, 2020). Lack of interaction between students and teachers affects learning process negatively and a significant learning gap occurs due to the prolongation of this process (World Bank, 2020b). Furthermore, it was determined that both students and families gave up on distance education process due to the prolongation of the quarantine. Similarly, relevant literature reports that families could find more opportunities to take care of their children and take more responsibility for their children's learning at the beginning of the pandemic, (Cai \& Wang, 2020). Along with all these, the most important problem unraveled by the findings is the inefficiency of educational practices for students with special needs. Unfortunately, many similar findings were found in terms of the education of students with special needs during the pandemic (Grayer et al., 2020; Kritzer \& Smith, 2020; Weale, 2020). Similarly, within situational reports and the results of studies, many children are reported not to carry out distance education properly because they are deprived of computer or Internet access due to financial insufficiencies in the world (Andrew et al., 2020; Fishbane \& Tomer, 2020; Onyema et al., 2020).

As can be understood from the findings of this research, psychosocial health risks were among other problems that emerged during the quarantine. During this period, it was found that students with special needs and their families were very depressed and bored due to their inability to go out and lack of interaction with their social environment. Accordingly, it was revealed that some students had severe conflicts with their siblings. This finding is consistent with those of several other studies. There are many research findings showing that families and children are overwhelmed during the restriction period (Asbury et al., 2020; Grayer et al., 2020; Weale, 2020). In the literature, it is recommended to provide psychological counseling services to support the psychological health of students and families during a pandemic (Akoğlu \& Karaaslan, 2020; Mustafa, 2020; Sahu, 2020). In Turkey, all students and parents who request help and guidance to maintain their psychological health are provided with information via telephone by MoNE Training and Guidance Services Information Line during the pandemic (MoNE, 2020a). Therefore, it can be said that teachers have important responsibilities in informing and guiding parents about the existence of such options. In addition, although family is the first interactional context of children, children need different social environments in order to develop physically, emotionally, and socially (Brazendale et al., 2017). Considering that the main purpose of inclusive education is to place students with special needs in the same educational and social environment with their peers, it can be said that inclusive education is important for both equal educational life and preparation for social life. Another problem that arose during the quarantine was the disruption of families' daily sleep patterns and routines. It can be said that lack of school and work life during the quarantine naturally causes a change in daily routines by eliminating the need to get up early in the morning.

During the pandemic, it was also found that almost all the participants expected teachers' attention and support regarding the education of their children. In a study conducted by Toseeb et al. (2020), which supports the finding of this study, it is emphasized that families need professional advice and support for the educational and psychological health needs of their children. It is known that some of the families still had to continue working during the pandemic. In such a case, it can be said that it would not be possible for them to encourage their children to learn and follow their distance learning processes. On the other hand, it is thought that families who do not have to work can encourage their children to learn and follow their education. At the same time, it can be argued that there may be opportunities to observe the effectiveness of their children's learning. However, it is stated that students need guidance from teachers in order to continue their education and to realize their learning (Cai \& Wang, 2020; Kritzer \& Smith, 2020; Mustafa, 2020). Considering the purpose of this research, it can be said that teacher support and guidance regarding the education of students with special needs is crucial and vital and necessary. Families also expect their children to be provided with technological tools such as computers and internet from charity organizations.

In this study, it was also figured that most of the students with special needs watched lessons on TV during the COVID-19 pandemic process and very few attended online courses. It was unveiled that teachers shared worksheets via WhatsApp groups. However, it is identified that teachers have failed in both guiding and supporting students with special needs \& their families and in providing them with instructional adaptations. Based on the opinions of families, one can state that the educational needs of students with special needs within inclusive education were not taken into account. However, it is frequently emphasized in the 
literature that the demographics, strengths and weaknesses of each student should be taken into account and their needs should be met in inclusive education (Friend \& Bursuck, 2012; Hornby, 2015; Mitchell, 2008; Turnbull et al., 2013). However, the results of this study show that students with special needs have not received equal and qualified education and have not been involved in any form of implementation in the context of integration during the pandemic process.

Leaning on this study's results, one can suggest that additional distance education be provided for students with special needs and their families through compensatory and preparatory education with special education services and adaptations at an appropriate time. It has been reported by the MoNE that teachers can work for compensatory and preparatory education in the summer on demand (MoNE, 2020b). However, considering that most of the students and families may be away from their homes or in rural areas in summer, the effectiveness of such a practice is shady. At the same time, compensatory education may not be carried out properly due to lack of computer and Internet access and lack of motivation to teach during the holiday. In such periods, counseling services should be systematically provided without the need for family requests in terms of psychological well-being as well as the education of students with special needs. In addition, the importance of strengthening and maintaining school-teacher-family-student cooperation, which is one of the important factors in the success of inclusive education, has been underlined one more time in this study. Considering the special needs of the children of participating parents in this study, it is possible to conclude that teacher guidance and follow-up is much more necessary in distance education process. Likewise, it may be beneficial to adapt the worksheets for children with special needs as part of the Individualized Education Programs. Based on all these data, one can suggest that IEP development units prepare a feasible program with teacher-family collaboration for the possibility of both face-to-face and distance education that can compensate the loss. On the other hand, future research endeavors can be directed to investigate teachers' opinions regarding distance education for students with special needs during the pandemic through qualitative designs.

\section{REFERENCES}

Akoğlu, G., \& Karaaslan, B. T. (2020). COVID-19 ve izolasyon sürecinin çocuklar üzerindeki olası psikososyal etkileri. İmir Katip Çelebi Üniversitesi Sağlık Bilimleri Fakültesi Dergisi, 5(2), 99-103.

Andrew, A., Cattan, S., Costa-Dias, M., Farquharson, C., Kraftman, L., Krutikova, S., Phimister, A. \& Sevilla, A. (2020). Learning During the Lockdown: Real Time Data on Children's Experiences During Home Learning (IFS Briefing Note BN288). The Institute for $\begin{array}{llllllll}\text { Fiscal Studies. } & \text { Retrieved } & \text { on } & 28 & \text { June } & 2020 & \text { from }\end{array}$ https://www.ifs.org.uk/uploads/Edited_FinalBN288\%20Learning\%20during\%20the\%20lockdown.pdf

Asbury, K., Fox, L., Deniz, E., Code, A., \& Toseeb, U. (2020). How is COVID-19 affecting the mental health of children with special educational needs and disabilities and their families? PsyArXiv Preprints. https://doi.org/10.31234/osf.io/sevyd

Bogdan, R. C., \& Biklen, S. K. (2007). Qualitative Research for Education: An Introduction to Theories and Methods. Boston: Pearson Education.

Cauchemez, S., Ferguson, N.M., Wachtel, C., Tegnell, A., Saour, G., Duncan, B., \& Nicoll, A. (2009.) Closure of schools during an influenza pandemic. The Lancet Infectious Diseases, 9, 473-481. https://doi.org/10.1016/S1473-3099(09)70176-8

Crabtree, B. F., \& Miller, W. L. (1999). Doing Qualitative Research (2nd ed.). Thousand Oaks, CA: Sage Publications.

Creswell, J. W. (2007). Qualitative Inquiry and Research Design: Choosing Among Five Approaches. Thousand Oaks, CA: Sage.

Doyle, O. (2020). COVID-19: Exacerbating educational inequalities? Public policy.ie. Retrieved on 10 June 2020 from http://publicpolicy.ie/papers/COVID-19-exacerbating-educational-inegualities/

Fishbane L., \& Tomer A. (2020). As classes move online during COVID-19, what are disconnected students to do? Retrieved on 9 June 2020 from https:/www.brookings.edu/blog/the-avenue/2020/03/20/as-classes-move-online-during-COVID-19-what-aredisconnected-students-to-do/

Friend, M., \& Bursuck, W. M. (2012). Including Students with Special Needs: A Practical Guide for Classroom Teachers. Boston Pearson.

Fry-Bowers, E. K. (2020. Children are at risk from COVID-19. Journal of Pediatric Nursing, 0882-5963(20)30317-1. https://doi.org/10.1016/j.pedn.2020.04.026

Given, L. M. (2008). The Sage Encyclopedia of Qualitative Research Methods. Los Angeles, Calif: Sage Publications. https://doi.org/10.4135/9781412963909

Grayer, A., Janrrent, L., \& Pomrenze, Y. (2020). Parents of teens with special needs find themselves alone in COVID-19 lockdown. Retrieved on 10 June 2020 from https://edition.cnn.com/2020/07/06/us/coronavirus-special-needs-educationwellness/index.html

Halder, N., Kelso, J. K., \& Milne, G. J. (2010). Developing guidelines for school closure interventions to be used during a future influenza pandemic. BMC Infectious Disease, 10, 221. https://doi.org/10.1186/1471-2334-10-221

Hornby, G. (2015). Inclusive special education: development of a new theory for the education of children with special educational needs and disabilities. British Journal of Special Education, 42(3), 234- 256. https://doi.org/10.1111/1467-8578.12101

Jackson, C., Mangtani, P., Vynnycky, E., Fielding, K., Kitching, A., \& Mohamed, H. (2011). School closures and student contact patterns. Emerging Infectious Diseases, 17(2), 245-247. https://doi.org/10.3201/eid1702.100458 
Kritzer, K. L., \& Smith, C. E. (2020). Educating deaf and hard-of-hearing students during COVID-19: What parents need to know. The Hearing Journal, 73(8), 32. https://doi.org/10.1097/01.HJ.0000695836.90893.20

Markham, A. (2004). Internet communication as a tool for qualitative research. Silverman, D. (Ed.). Qualitative Research: Theory, Method, and Practices, London: Sage.

Mertens, D. M. (2010). Research and Evaluation in Education and Psychology: Integrating Diversity with Quantitative, Qualitative, and Mixed Methods. USA: Sage publications.

Miles, M. B., \& Huberman, A. M. (1994). Qualitative Data Analysis. Thousand Oaks, CA: Sage Publications.

Mitchell, D. (2008). What Really Works in Special and Inclusive Education: Using Evidence-Based Teaching Strategies. Abingdon, Oxfordshire: Routledge. https://doi.org/10.4324/9780203029459

MoNE. (2012). Millî Eğitim Bakanlığı Özel Öğretim Kurumları Yönetmeliği. Retrieved on 19 June 2020 from http://ookgm.meb.gov.tr/meb_iys_dosyalar/2020_02/25111828_Ozel_Ogretim_Kurumlari_Yonetmeligi_19022020.pdf

MoNE. (2019). Milli Eğitim istatistikleri, Örgün Eğitim. Retrieved on 19 June 2020 from http://sgb.meb.gov.tr/meb_iys_dosyalar/2019_09/30102730_meb_istatistikleri_orgun_egitim_2018_2019.pdf

MoNE. (2020a-January-March). E-Özel, Özel Eğitim ve Rehberlik. Retrieved on 29 May 2020 from http://ookgm.meb.gov.tr/meb_iys_dosyalar/2020_05/18020440_E_Bulten_2020_01_b.pdf

MoNE. (2020b). Çerçeve Yaz Tatili Programı Retrieved on 25 July 2020 from http://sgb.meb.gov.tr/meb_iys_dosyalar/2020_07/13120827_cerceve.docx

Monto, A. S., Davenport, F. M., Napier, J. A., \& Francis, T. Jr. (1969). Effect of vaccination of a school-age population upon the course of an A2/Hong Kong influenza pandemic. Bull World Health Organ, 41, 537-541.

Moustakas, C. (1994). Phenomenological Research Methods. Thousand Oaks, CA: Sage. https://doi.org/10.4135/9781412995658

Mustafa, N. (2020). Impact of the 2019 - 20 coronavirus pandemic on education. International Journal of Health Preference Research, 1-36. https://doi.org/10.13140/RG.2.2.27946.98245

Onyema, E. M., Eucheria, N. C., Obafemi, F. A., Sen, S. Atonye, F. C., Sharma, A., \& Alsayed, A. O. (2020). Impact of coronavirus pandemic on education. Journal of Education and Practice, 11, 13. https://doi.org/10.7176/JEP/11-13-12

Orgilés, M., Morales, A., Delvecchio, E., Mazzeschi, C., \& Espada, J. P. (2020). Immediate psychological effects of the COVID-19 quarantine in youth from Italy and Spain. PsyArXiv Preprints. https://doi.org/10.31234/osf.io/5bpfz

Özer, M. (2020). Educational policy actions by the ministry of national education in the times of COVID-19. Kastamonu Education Journal, 28(3), 1124-1129. https://doi.org/10.24106/kefdergi.722280

Petretto, D. R., Masala, I., \& Masala, C. (2020). Special educational needs, distance learning, inclusion and COVID-19. Education Sciences, 10(6), 154. https://doi.org/10.3390/educsci10060154

Reichert, T. A., Sugaya, N., Fedson, D. S., Glezen, P., Simonsen, L., \& Tashiro, M. (2001). The Japanese experience with vaccinating schoolchildren against influenza. N Engl J Med. 344, 889-896. https://doi.org/10.1056/NEJM200103223441204

Sahu, P. (2020). Closure of universities due to coronavirus disease 2019 (COVID-19): Impact on education and mental health of students and academic staff. Cureus, 12(4), e7541. https://doi.org/10.7759/cureus.7541

Schaeffer, K. (2020). As schools shift to online learning amid pandemic, here's what we know about disabled students in the U.S. Retrieved on 30 May 2020 from https://www.pewresearch.org/fact-tank/2020/04/23/as-schools-shift-to-online-learning-amidpandemic-heres-what-we-know-about-disabled-students-in-the-u-s/

Toquero, C. M. D. (2020). Inclusion of people with disabilities amid COVID-19: Laws, interventions, recommendations. Multidisciplinary Journal of Educational Research, 10(2), 158-177. https://doi.org/10.4471/remie.2020.5877

Toseeb, U., Asbury, K., Code, A., Fox, L., \& Deniz, E. (2020). Supporting families with children with special educational needs and disabilities during COVID-19. PsyArXiv Preprints. https://doi.org/10.31234/osf.io/tm69k

Turnbull, A. Turnbull R., Wehmeyer, M. \& Shogren, K. (2013). Exceptional Lives: Special Education in Today's Schools (7th Ed). Pearson.

Van Lancker, W., \& Parolin, Z. (2020). COVID-19, school closures, and child poverty: A social crisis in the making. Lancet Public Health, 5(5), e243-e244. https://doi.org/10.1016/S2468-2667(20)30084-0

Weale, S. (2020). English schools 'using coronavirus as excuse' not to teach special needs pupils. Retrieved on 15 June 2020 from https://www.theguardian.com/education/2020/jul/01/english-schools-using-coronavirus-as-excuse-not-to-teach-specialneeds-pupils

WHO (2020). Coronavirus disease (COVID-19) situation dashboard. Retrieved on 6 September 2020 from https://COVID19.who.int

World Bank. (2020a). Remote learning, distance education and online learning during the COVID19 Pandemic: A resource list by the world bank's edtech team (English). Retrieved on 26 June 2020 from http://documents.worldbank.org/curated/en/

World Bank. (2020b). Educational policies in the COVID-19 pandemic: What can Brazil learn from the rest of the world? Retrieved on 15 June 2020 from http://pubdocs.worldbank.org/en/511671585947801777/EDUCATIONAL-POLICIES-IN-THE-COVID-19PANDEMIC-WHAT-CAN-BRAZIL-LEARN-FROM-THE-REST-OF-THE-WORLD.pdf

Zheng, B. (2020) The ninth press conference on the prevention and control of new crown pneumonia in Henan Province. Retrieved on 15 June 2020 from http://www.haedu.gov.cn/nyqfbh/index.html 
Zhou, L., Li, F., Wu, S. \& Zhou, M. (2020). School's out, but class's on, the largest online education in the world today: Taking China's practical exploration during the COVID-19 pandemic prevention and control as an example. Best Evid Chin Edu, 4(2), 501-519. https://doi.org/10.15354/bece.20.ar023 